\title{
DIFFERENTIAL GENDER APPROACH FOR GIRLS OF THE AGE OF 12-15 IN THE PROCESS OF BOXING TRAINING
}

\author{
Anatolii Konokh \\ Doctor of Pedagogical Sciences, Professor, Head of the Department of Theory and Methods \\ of Physical Culture and Sports, Zaporizhzhia National University, Ukraine \\ e-mail: Konoch105@ukr.net, orcid.org/0000-0003-4283-9317
}

Artur Vorontsov

Postgraduate Student, Zaporizhzhia National University, Ukraine e-mail: vai77@ukr.net, orcid.org/0000-0002-3269-273X

\section{Summary}

The article presents the substantiation of the differential gender approach to the training for the girls of the age of 12-15 years in boxing. Methods. Theoretical analysis of special and scientific literature, generalization of data. Results. Several sides of Boxing preparation in general are considered. The physiological features of the female organism and the level of influence of certain phases of the menstrual cycle in training and competitive activities, sensitive periods of development of physical qualities and capabilities of girls contribute to the training and improvement of physical exercises in training are studied. The difference was detected: in the volume of training loads for boxers' girls of 12 years old compared to girls-boxers of 15 , in methods of teaching technical and tactical training of girls of 12-15 years old compared to men and boys boxers. The interconnection of various aspects of preparing girls in boxing is determined. A differential gender approach to girls training is offered. Conclusion. The results of the completed theoretical analysis revealed ways of effective education, improving technical and tactical training of girls of 12-15 years old dealing with boxing which should be noticed in effective performances at competitions of different rank. The actual directions of combination and increase in the volume of theoretical preparation with psychological in the training process were revealed. Differential exercise by age. Variation of means of training when mastering and improving tactical, technical education directly with a partner in pairs or in a training fight. In the long run, with this approach it is possible to create a well-grounded (with a clear distribution of training load) a conceptual model of training, which involves harmonious training of girls engaged in boxing.

Keywords: Virgin Boxing, Boxing Preparation, Boxing Workout, Girl Workout, Pedagogical Approach, Integrated Approach.

DOI: https://doi.org/10.23856/4407

\section{Introduction}

In connection with the rapid development of women's boxing in the world, an increase in classification competitions at the international level, international tournaments and joint educational training fees, increased the number of competitions within the country, which contributed to the popularization of this sport among girls and more attention from sports functionaries. Thus, the issue of the development of the youngest age groups of female boxing in order to prepare the reserve in the future and strengthening the international image of Ukraine as a "boxing state" in competitions of these age groups in the future. 
Unfortunately, the small amount of scientific and special literature on boxing dedicated to the training of younger age groups complicates this process. Therefore, trainers working with this age group are guided by methodological developments in other sports in which the preparation of girls of this age already has certain levels: athletics, tennis, judo wrestling, gaming types, art and sports gymnastics, acrobatics, and cycling sports. Use templates for technical and tactical training in boxing, which are inherent in the training of boys, highly skilled men and women boxers.

The purpose of the study: to substantiate theoretically the expediency of training with the help of a differential gender approach for girls of 12-15 years old in boxing.

Material \& methods. To find out the problem field of the selected topic, the determination of the object, subject, the purpose and substantiation of the results used the method of the theoretical analysis of special and scientific literature, the Internet, generalization of data.

Implementation of this method was carried out by analyzing and generalizing the data of scientific literature and experience in domestic and foreign practices on the preparation of athletes, regardless of sex in various sports and boxing. The study and generalization of scientific literature on the subject of the article was carried out according to educational and methodical manuals, scientific articles of professional scientific journals, materials of conferences, dissertation and dissertation robots, leading scientific Internet resources.

\section{Theoretical analysis of scientific literature}

Studied the scientific works of various periods of leading trainers, scholars, trainers of team teams of different countries Cokes \& Kayser (1980), Radko, Bielykh, Iusov, Sternikova \& Vorobiov (2003), Driscoll (2008), Edwards (2008), Ostyanov (2011), Lisicyn (2014), Gasanova (2014) the author of the article determined that in technical and tactical training in meil and female boxing there is a certain component: a sequence of teaching techniques of strikes, movements, protective actions and fundamental teaching methods. Although in teaching the technique of the sequence of impacts there are certain differences, for example, after learning jabs, some coaches recommend teaching hooks, and then uppercuts. Also, trainers' views may vary in the distribution of priorities in learning, for example, focus on attacking actions and then pay attention to learning and improving defensive actions. However, on the technique of execution of strikes and defensive actions and special moving, according to the authors of the article, such an algorithm does not affect. The differences of approaches in training depends on the boxing traditions inherent in one or another country, modern trends in sport and changing of rules in boxing.

Domestic and foreign scholars, specialists in women's boxing Chaterjee, Banerjee, MajumDar \& Chatterjee P. (2006), Gasanova (2015), Saktaganova (2015), pay attention to what has a little studied physiological and psychological side of female boxing, so transporting training Templates from a male training program without taking into account a physiological and psychological component, in a women's training program is invalid (Ryasnaya, Shevchenko A. \& Shevchenko I, 2014; Gasanova, 2015).

Scientists who work with athlete women for decades prove that the phase of the menstrual cycle (MC) affects not only the training process, also on the indicators of sports outcome and behaviour during training and competitions. For promenonstrial, ovulatory and menstrual phases, MC is characterized by a decrease in the speed of the latent period of a simple visual-motor reaction and complex visual-motor reactions, reducing the rate of change in the processes of excitation and braking in the central nervous system (Shakhlina \& Chistyakova, 2020). 
Mark the smallest efficiency of blood circulation and the use of energy resources of the body with physical activity, slowing down of motor reaction, reduction of strength, endurance, increasing mobility in joints and stretching of the ligament apparatus. Sweating in physical activity begins earlier, which is reflected in the sensitivity to increase ambient temperatures. Adaptation to physical activity is more stressful, and the restorative period will be stretched (Shakhlina, 1999). Examined 974 athletes in various types of sports in particular in acyclic sports, proved that in the face phase, the effectiveness of training a number and is from $43.5 \%$ to $80.3 \%$, depending on the sport, with the exception of artistic gymnastics in which the efficiency was $80.5 \%$. The high performance in the competition among the investigations was not found among the representatives of acyclic sports, the smallest gap between the high and low result in the indicators was 6\% towards a low result in representatives from Freestyle and 7.6\% of basketball representatives. In other sports, the difference in the direction of low result in phases of MC amounted to 30.4 (hockey on the grass) to $100 \%$ (modern pipeborne) (Shakhlina \& Kovalchuk, 2018).

The data of specialists in sports medicine claims to influence the MP phases to lateral asymmetry, which will negatively affect the level of assimilation of coordination exercises and on the level of functional asymmetry in general, although according to specialists in psychophysiology in women in general, a small difference in manual asymmetry compared with men (Vorontsov, 2020: 14-19).

Scientists prove that women in certain periods of MC are more difficult to solve spatial tasks (Bendas, 2006). Prone to raising the level of anxiety, inattention (Armento et al., 2021). Prone to risk increasing lower extremity injuries than boys at all (Lehnert et al., 2020), and in certain phases IC, this risk increases (Lee \& Petrofsky, 2018).

Therefore, experts recommend to correct the amount of recovery tools that should be $25 \%$ more than men depending on the personality and cyclic load changes to prevent such cases. However, it is possible to prevent such cases by differentiation by means and methods of physical training (Nerobeev, 2014).

That is, these data, according to the authors of the article, certify the integral influence of the phases of the biological cycle of the female body in training. Therefore, they need a coach of competence in the educational process when training women's gender.

According to the research due to a differential gender approach in which the MC phases were taken into account, the level of successful performance on competitions in various sports such as basketball, treadmills athletics and jumps, in the female gender due to the use of this method increased from $30 \%$ to $56 \%$, depending on gender type and kind of sport (Shevchenko, 2014). Also, due to this method, indicators of special physical training of volleyball players increased depending on the gender type (Artamonova \& Shevchenko, 2016).

Other scientists working with highly skilled women in various sports including the martial arts argue that a differentiated gender approach depends on the typological features of a woman athlete and such personalities can train by a male program without account phases MC (Nerobeev, 2014; Artamonova \& Shevchenko, 2014; Kostyuchenko, Vrublevskij \& Kozhedub, 2017).

Observed by the authors of the article scientific works of leading specialists in the field of sports medicine, coaches work with women athlete Soboleva \& Sobolev (2013), Bugaevskij (2017), Bugaevskij (2017), Tarasevych \& Mulik (2020), and others, in which it has been proved that the different gender type of personality are capable to react on different ways to physiological mental and physical activity, determined that various sports activities, sports experience affect the formation of gender identity of athletes. Scientists determine the following 
gender types: masculins, androgins, femines. Qualities that make up masculinity content in sports: activity, independence, independence, courage, assertiveness, perseverance, manifestation of will, ability to resist hardship, ability to achieve the goals, readiness for risk, with high self-esteem and self-oriented success. Sports doctors and specialists in various types of sports and women's boxing determine that in this type is increased concentration of androgens, which positively affects the development of physical qualities such as the stroke of movements, speed, endurance. In the psychophysiological plan will be manifested in underestimation of anxiety and an adequate response to stress. Testosterone will help improve different types of memory, spark orientation, concentration of attention. According to experts, the versatility of the androgine type in various sports is in a manifestation in case of necessity of feminine and masculine characteristics of character (situational flexibility, ability to centering their interests as necessary), better adaptation to new conditions, interpersonal contacts in the team. The feminine type includes properties such as passivity, softness, care, emotionality, sensitivity, shyness, readiness to help, compliance, sensitivity, tenderness, ability to compassion and empathy (Vorontsov, 2020: 95-101).

According to empirical studies on various sports in particular in sports martial arts, the bulk of the athletes consists of androgenic and masculine gender representatives (Burdzicka-Wolowik, 2012; Burdzicka-Wolowik \& Goral-Radziszewska, 2014; Tarasevich \& Kamaev, 2019; Bojkowski \& Kalinowski, 2014; 2019; Vorontsov, 2020: 95-101).

According to physiologists, according to the number of muscle fibers, women are not inferior to men, but women are inferior to the thickness of muscle fibers, if they are engaged in a single sport and have approximately the same qualifications with men. The presence of slow fibers in muscles in women is approximately the same with men. Indicate that arbitrary maximum muscle strength to the puberty period is the average of girls and boys, but after 12-14 years old in the girls are smaller. Training of muscle strength ie ability to increase muscle strength under the influence of directed power training in women relatively less. Most noticeable in 16-30 years, less it is noticeable in 12-14 years, which indirectly indicates the important role of androgens in the development of muscle strength. The concentration of lactic acid after maximum aerobic work in women is smaller (Kots, 1998).

According to scientists in experiments associated with elevation, women are able to carry out the same power tasks as men, but with a certain kind of technical execution (Lindbeck \& Kjellberg, 2000).

Specialists of Blagrove et al., (2018) Recommend for teens - girls Moderate loads in order to prevent injury and increase of power qualities when training 2-3 times a week with a progressive load by $5-10 \%$ for 10 weeks.

According to the authors, the differential gender approach becomes relevant not only in between sex groups, but also in age groups of female boxing. Consequently, these data allow us to conclude about the influence of the physiological formation of the maiden organism and sporting experience on the quality of preparation in this sport.

Scientists determined the level of stabilization of the basic physiological systems of the maiden's body, the development of physical qualities, which accounts for 15 years, depending on the individual necessary to increase the physical activity of training, digestion and improvement of special motor operations in Boxing (Lisicyn, 2014: 65; Konokh \& Vorontsov, 2019: 232-238). That is, increased physical activity in order to develop muscle strength, anaerobic loads are expedient from this age.

The researcher determines that the increased volume of general physical activity for girls can be 8 years, 11 years, 15 years and older. In other ages, small and middle (Volkov, 1981: 69). 
The authors of the article states that sensitive periods of physical qualities make coaches to change the approaches and more individualize it, because certain physical qualities that are needed to master the physical exercises and skills development can be lost.

The empirical data of leading scholars analyzed by the authors allowed to assume that such qualities as the power dynamic endurance of the flexors of the body, the power dynamic endurance of the trunk extensor, the static endurance of the shoulder flexors, loses development in accordance with 13,12, 11 years. The speed of response to simple and complex situations develops up to 14 years, construction of motor activities and dynamic equilibrium finish developing in 13 years, static equilibrium develops up to 14 years, the accuracy of the single movement stops developing in 12 years. The highest development of the rate of movement of the lower extremities ends in 11 years, but evenly high level of growth is observed in 15-16 years. The level of change in the degrees in the joints when moving the body in space directly in the shoulder and elbow, better changes to 12 years. Undoubtedly, in the opinion of the authors of the article, especially when adjusting the techniques of performing lateral and strikes from below from 45-120 degrees. Also, scientists pay special attention to the age of 11-13 years in girls in which it is necessary to work purposefully on the development of the reaction to 12 years, also in these years, the maximum growth of bones of the pelvis 12-13 years, the completion of the development of a motor analyzer 11-12 years old which contributes to the thin differences in the temporary and spatial characteristics of movement, which helps to better and more rapid assimilation of motor skills and assimilation of wavy displacement of the body in space from 11-12 years. The study of scientists in complicated coordination from 7-8 years to 12-13 years has proven that the interest assimilation of physical exercises in children greatly increases, after it remains in place (Konokh \& Vorontsov, 2019: 115-119; Vorontsov, 2019: 35-48).

That is copying the training process of highly skilled women-boxers is not relevant for maiden boxing. Since the preparation of girls is complicated by the fact that studying in basic training groups accounted for a puberty period in which physical training will have to train adult women - boxers, there are also certain differences in the volume of training load, according to the physiological purpose of training, the complexity of technical elements.

Scientists from sports psychology are drawn to the significance and multivectoral psychological training. Scientists show that today in a highly skilled sport level of physical activity, functionality, record indicators practically achieved its boundaries and require a more detailed study of the psychological component to increase skills and skills. (Vysochina \& Vorobiova, 2019). Attention is drawn to the detection in the initial stages of many years of training of certain psychological differences in personality that directly affect to the level of mastering and improvement of physical exercises. In the training process, when performing technical exercise, monotony develops faster in representatives with a "strong" nervous system. Representatives with "weak" nervous system show a high density in the first part of the class or task. Individuals with a "strong" nervous system and the inertia of the nervous processes are better conducting "ends" of tasks. Representatives with the "weak" nervous system and the mobility of the nervous processes are better "enter" in physical work, but the "end" of the task is spoiled. The time of complex reaction is the smallest in representatives with the "weak" and "strong" types of the nervous system. Physical quality as endurance - may be the same in individuals with a "strong" and "weak" nervous system. Load on training with small and medium intensity increases the efficiency in all individuals with different types of nervous system. At the stage of representation of the molding of the motor skills of individuals with weak type of nervous system and the average degree of mobility of excitation is more successful in mastering such movements. At the stage of improvement, the initiality of memorization of physical exercises is 
better in athletes with the inertia of nervous processes. And in capturing at the tempo of study in individuals with lability and mobility of nervous processes. Subsequently, inert athletes are compared as skills with athletes of mobile nerve processes. It is noted that when breaks in training classes are better maintained in inert athletes (Ilin, 2008).

According to the tactics in the sport of individuals with a weak nervous system and moving nervous processes are inherent in protective and counterattacking actions. Attacking style is more suitable for individuals with a strong nervous system and the inertia of the excitation of nervous processes. Athletes with a weak nervous system are effective in the role of "fleeing", and athletes with a strong nervous system in the role that is recovered with treadmills and mobile games (Ilin, 2008; Radionov \& Radionov, 2013).

Scientists point out the destruction of psychological conditioning in women in comparison with men in the training process in general (Bendas, 2006; Lisitsin, 2014).

Sports psychologists focus on an important component in preparing women boxers, such as aesthetic pleasure from the training process, generally mark high social activity (Predelskaya, 2015).

On the example of the female boxing team of Kazakhstan a scientist emphasizes the significance of balanced mental and physical training, ability to manage a stressful situation during competitions and training periods. Insists on accompanied by a psychologist at all stages of workout, because a negative psychological mood - the main reason for an unsuccessful performance in competitions even in highly skilled athletes. Attention is drawn to a small number of psychological training in an annual training plan, according to its data, such training occupies only $10 \%$ (Saktaganova, 2018).

Head coach of the Female National RF 2003-2017, Scientist V.V. Lisitsin believes that one of the priority directions should be considered in the training of Boxing School Boxers, where technical and tactical training is associated with physical and psychological. It prevents the inadmissibility of the frequency of matches in female boxers compared to the battles in men-boxers, since they negatively act on the nervous system, which can lead to a refusal to speech (Lisicyn, 2014: 94 - 126, 189).

A significant number of scientists focus on the theoretical component in the training of boxers. Of course, such training assumes a certain intelligence and abilities.

Scientists have proven intellectual advantage of women engaged in acyclic sports over women cyclic sports and women who do not engage in sports in general (Pacesova, Smela \& Nemcek, 2020).

Studies prove the benefits of girls 14-15 years of arbitrary attention that are focused on speed (according to the scope, stability and distribution of attention) (Il'in, 2002).

The advantage of template, memorization with the help of vision (9-12 years) and on hearing, content memory (12-14 years). The dominant verbal and election memory with the name of the subject (Bendas, 2006) is to have a tendency to more memorable materials painted in pictures with a description of the action. What, according to the authors of the article, implements the application of project tests in the theoretical training of the Boxing Tactics of this age group.

According to these researchers, the theoretical component at the stage of basic preparation raises interest in athletes on the following topics: "Varieties and content of tactical techniques and actions" and "Strategy and Tactics of Competitive Activity". According to trainees from martial arts, the appropriateness of the theory lies in the ability to develop tactical thinking of its practical application. In order to assimilate the above-mentioned material, according to experts, the following verbal methods: Analysis and Discussion, Guidelines and Recommendations, 
Videos should be used. In practical methods: workout with a partner and conditional rival (Zadorozhna, Briskin, Sosnovskyy, Romanyuk \& Ryhal, 2019: 46-51; Zadorozhna, Briskin, Pityn, Perederiy \& Neroda, 2020: 71 -85).

\section{Discussion and recommendations}

As you can see from the aforementioned boxing preparation, it consists of several directions that are interconnected and necessary for a rational training process.

Having considered means and methods of technical and tactical training in boxing in sources written above and relying on its own practical experience, author was concluded that the main means and methods of female TTP practically do not differ from male. Of course, the methods of training and improvement have suffered certain innovative changes, such as training special technical and tactical exercises using an active video game (AVG), virtual reality simulators (Aygün \& Çakır-Atabek Hayriye, 2018; Balko Heidler \& Edl T., 2018; Akbas et al., 2019). However, the main means of the TTP remain "Boxing School", working with a partner in a pair (working out tasks), sparring with different styles of rival in conditional and free battles. These means, according to the authors of the article, can be used in the training of girls in this age group, but with a certain differentiation. For example, reduce the volume of free battles for girls and young people when working in a pair compared to boys, but to give a larger share of conditional battles with a certain task, more often change the tasks, providing tasks depending on the somatotype (weight category). However, to proceed to training classes that to study and improve the technical and tactical skill of girls in this age group with the help of these major Boxes, according to the authors, requires various methodological ways.

In certain phases MC should be avoided larger in terms of physical activity aimed at developing force, endurance, speed. This approach, in the opinion of the authors, will not violate power training in a weekly microcycle as data provided (Barbalho et al., 2019) indicates that the development of power qualities in women can grow even when training once on Sunday with 10 approaches in the 24 weeks. Exercises associated with jumps in different variants should be taken from a training program. The selection of encumbrances for training in these phases should be minimal because mobility in the joints and reducing the strength of the skeleton bones can lead to injuries, especially lower extremities.

In the training and improvement of technical and tactical training in certain phases IC it is advisable to reduce the training of new high coordination exercises are particularly related to functional asymmetry. The role of the visual analyzer is weak and appropriate to use auditory modality with various types of sensory signals: cotton, pivot, conditional slang coach, Danes of specialists Benešová \& Švátora (2018). In a psychological plan, a decrease in the training of emotional tension, and an increase in the use of autogenous training methods. Involvement in the planning of the training process of athletes, solving issues regarding the selection of training exercises with the help of creative tasks during and outside the training process.

In theoretical training in phases $\mathrm{MC}$, the expediency of using conversation methods, project tests, educational films.

In other phases, power loads for girls 12-13 years are possible at the level with guys this year, because the power potential is practically the same. But with differentiation by the number of repetitions in exercise and approaches. By the volume of training load, such physical work can be enlarged for girls in 15 years.

In the technical and tactical plan, in connection with the already formed motor analyzer, which will be in 12-13 years in girls, the expediency of learning the assembly of difficult 
coordination movements. That is, it is possible to improve the series of 3 and more strikes, as well as repeated attacks with the same amount of strikes. Taking into account the speed of the legs in this period in girls, a greater propensity to mastering stereotyped movements and a small manual asymmetry technical and tactical arsenal of boxers will be further supplemented. For example: the transition from attack to active protection with impacts and the subsequent transition to a counter attack requires a boxer application of four and more strikes. That requires high coordination boxer, the accuracy of the movement of the legs, a sense of space that is possible for the maturity of the motor analyzer.

Also, when studying asymmetric exercises, specialists recommend training from the dominant side in 15 years, and from the leader of 12.5-13.5 years (Vorontsov, 2020:14-19).

Theoretical training should be carried out in breaks between training tasks and evaluate the level of execution with video shooting directly after the training exercise.

\section{Conclusions}

The results of the completed theoretical analysis revealed ways of effective education, improving technical and tactical training in girls 12-15 years dealing with boxing. Which should manifest themselves in productive speeches in competitions of different rank.

The actual directions of combination and increase in the volume of theoretical preparation with psychological in the training process were revealed. Differential exercise by age. Variation of learning tools when mastering and improving tactical, technical training directly with a partner in pairs or in a training fight.

In the long perspective, with this approach it is possible to create a well-grounded (with a clear distribution of training load) a conceptual model of training, which involves harmonious training of girls engaged in boxing.

\section{References}

Akbas, A., Marszalek, W., Kamieniarz, A., Pelechonski, J., Slomka, K.J., \& Juras, G. (2019). Application of virtual reality in competitive athletes-a review. Biomedical Human Kinetics, 69, 5-16. doi: 10.2478/hukin-2019-0023 [in English]

Armento, A., VanBaak, K., Seehusen, C. N., Sweeney, E. A, Wilson, J.C. \& Howell D. R. (2021). Presence and Perceptions of Menstrual Dysfunction and Associated Quality of Life Measures Among High School Female Athletes. J Athl Train Vol. 56, Issue 2 (feb.). doi.org/10.4085/624-20 [in English]

Artamonova, T.V. \& Shevchenko, T. A. (2014). Analiz napravlennosti pedagogicheskogo vzaimodejstviya $v$ rabote s genderno differencirovannymi sportsmenami [Analysis of the educationally targeted interaction in the work with the gender-differentiated athletes]. Uchenye zapiski, 5(111), 16-19. doi: 10.5930/issn.1994-4683.2014.05.111.p.16-19 [in Russian]

Artamonova, T.V. \& Shevchenko, T. A. (2016). Povyshenie urovnya specialnoj podgotovlennosti yunyh volejbolistok na osnove genderno differencirovannogo podhoda [Improving the special training of the young volleyball players on the basis of gender differentiated approach]. Uchennyye zapiski Universiteta imeni P.F. Lesgafta, 4 (134), 25-29. DOI: 10.5930/ issn.1994-4683.2016.04.134.p25-29 [in Russian]

Aygün, Cihan \& Çakır-Atabek, Hayriye. (2018). The futuristic model for physical activity and exercise: active video games. Phys Activ Rev., 6, 45-53. doi: 10.16926/par.2018.06.07 [in English] 
Balko, S., Heidler, J. \& Edl T. (2018). Virtual reality within the areas of sport and health. Trends in sport Sciences, 4(25),175-180. DOI: 10.23829/TSS.2018.25.4[in English]

Barbalho, M., Coswing, V.S., Steele, J., Fisher, J.P., Paoli, A. \& Gentil P. (2019). Evidence for an upper threshold for Resistance training. Medicine \& Science in sports \& Exercise, 51,(3), 515-522. DOI:10.1249/ MSS.0000000000001818[in English]

Bendas, T.V. (2006). Gendernaya psihologiya [Gender psychology]. St. Petersburg: Piter. [in Russian]

Benešová, D. \& Švátora, K. (2018). Influence of increase of sensomotor task difficulty on neural system arousal and motoric performance. Trends in sport Sciences, 4(25), 217-233. DOI: 10.23829/TSS.2018.25.4-7 [in English]

Bielykh, C.I.,Iusov V.L., Shaternikova, A.A., \& Vorobiov, O.O. (2003). Divochyi boks [Girly boxing]. Chernivtsi : Bukovynska derzhavna medychna academia. [in Ukrainian]

Bojkowski, L. \& Kalinowski, P. (2019). Psychological gender of sportsmen in team sports. Trends in sport sciences, 3(26). P. 113-116 DOI: 10.23829/TSS.2019.26.3 [in English]

Blagrove, R., Howe, L., Cushion, E., Spence, A., Howatson, G., Pedlar, C., \& Hayes P. (2018). Effects of strength training on postpubertal adolescent distance runners. Medicine \& Science in sports \& Exercise, 50, 6 (june). P. 1224-1232. DOI: 10.1249/MSS.0000000000001543 [in English] Burdzicka-Wolowik, J. (2012). Psychological gender of women taking uptypically masculine sports activity. Biomedical Human Kinetics 4, 24-28. DOI:10.2478 / v 101001012-0005-1[in English]

Burdzicka-Wolowik, J. \& Goral-Radziszewska, K. (2014). Selected personality trains of women training combat sport, Pol.j.Sport Tourism, 21, 3-7. DOI: 10.2478 / pjst-2014-0001 [in English]

Chatterjee, P., Banerjee, A.K., Majumdar, P. \& Chatterjee, P. (2006). Energy expenditure in women boxing. Kathmandu: Univ. Med. J. (KUMJ). 4(3). 319-23. [in English]

Cokes, C. \& Kayser, H. (1980)The Complete book of boxing for fighters and fight fan. Promethean Press. [in English]

Driscoll, O. Ringcraft. (2008). Promethean Press. [in English]

Edwards, W. (2008). Art of boxing and manual of training. Promethen Press. [in English]

Gasanova, S. (2015). Osobennosti sorevnovatelnoj deyatelnosti vysokokvalificirovannyh zhenshin-bokserov [Features of competitive activity of highly qualified female boxers]. Sportivnyi vestnik Pridneprovia, 3, 25 - 28. [in Russian]

Gasanova, S.F. (2014). Zhinochyi boks [Women's boxing]. Kyiv: National University of Construction and Architecture [in Ukrainian]

Hanuel, Lee \& Jerrold Petrofsky. (2018). Defferences between men and women in balance and tremorin relation to blantarfascia laxity during the menstrual cycle. Journal of Athletic Training. Vol.53.No 3(mart). P. 255-261. URL :http: ntjuournals.org./doi/full/10.4085/1062-6050-217 [in English]

Il'in, E.P.(2003). Differencialnaya psihologiya muzhchin i zhenshin [Differential psychology of men and women]. St. Petersburg: Piter. [in Russian] Il'in, E.P. (2008).) Psihologija sporta [Sports psychology]. St. Petersburg: Piter. [in Russian]

Konokh, A. \&Vorontsov A. (2019). Obuchenie tehniko-takticheskoj podgotovke devochek $v$ gruppah bazovoj podgotovki po boksu [Teaching technical and tactical training for girls in basic training groups in boxing]. Fizychne vykhovannia i sport $v$ navchalnykh zakladakh Ukrainy na suchasnomu etapi: stan, napriamky ta perspektyvy rozvytku 2019 [Proceeding's of the Physical education and sport's in primary school's of Ukraine at the present: stage, state, directions and prospect's of development 2019] Kharkiv : Ozerov G.V.,115-119. [in Russian] 
Konokh, A. \& Vorontsov, A. (2019). Priorytetni napriamy vdoskonalennia systemy pidhotovky $v$ zhinochomu boksi [Priority areas for improving the training system in women's box]. Sportyvnyi visnyk Prydniprovia, 3, 11 - 18. DOI: 10.32540/2071-1476-2019-3-011 Retrieved from: http://infiz.dp.ua/joomla/index.php/science/sportivnij-visnik-pridniprov-ya/16-zhurnal/232svp-2019-3 [in Ukrainian]

Kostyuchenko, V.F., Vrublevskij, V.P., \& Kozhedub, M.S. (2017). Metodika individualizirovannoj podgotovki sportsmenok $v$ godichnom cikle, specializiruyushihsya $v$ sprinterskom bege [Methodology of individualized training of athletes in the year-cycle specializing in sprint]. Uchenye zapiski universiteta im. P.F. Lesgafta, 10(152), 115-121. Retrieved from: https:// cyberleninka.ru/article/n/metodika-individualizirovannoy-podgotovki-sportsmenok-v-godichnom-tsikle-spetsializiruyuschihsya-v-sprinterskom-bege [in Russian]

Koc, Ya.M. (1998). Sportivnaya fiziologiya.[Sports physiology]. Moscow: Fizkultura i sport. [in Russian]

Lehnert,M., De Ste Croix, M., Svoboda, Z., Elfmark, M., Sikora, O. \& Stastny P. (2020). Gender and age related differences in leg stiffness and reactive strength in adolescent team sports players. Journal of Human Kinetics, 74, 119-129 DOI: 10.2478/hukin-2020-0020 [in English] Lindbeck, L. \& Kjellberg, K. (2000). Gender differences in lifting technique. Ergonomics, 44(2), 202-214. [in English]

Lisicyn, V.V. (2014). Specifika tehniko-takticheskoj podgotovki zhenshin-bokserov vysokogo klassa [Specific tehnical and tactical training of women-high class boxers]. Moscow: Lenand. [in Russian]

Lisicyn,V.V. (2015). Tehniko-takticheskaya podgotovka vysokokvalificirovannyh zhenshin bokserov [Technical and tactical training of highly qualified female boxers]. (Master's thesis). FGBU FNCFKiS, Moscow. [in Russian]

Radko, M.M., Bielykh, C.I.,Iusov V.L., Shaternikova, A.A. \& Vorobiov, O.O. (2003). Divochyi boks [Girly boxing]. Chernivtsi : Bukovynska derzhavna medychna akademia. [in Ukrainian] Nerobeev, N. Yu. (2014). Fizicheskaya i tehniko-takticheskaya podgotovka sportsmenok v volnoj borbe $s$ uchetom vliyanij polovogo dimorfizma [Physical and technical-tactical training of female athletes in freestyle wrestling, taking into account the effects of sexual dimorphism]. (Master's thesis). Lesgaft National State University, Sankt-Peterburg.[in Russian] Ostyanov, V.N. (2011). Obuchenie i trenirovka bokserov [Education and training boxer]. Kyiv: Olimpijskaya literatura. [in Russian]

Pacesova P., Smela P.\& Nemcek D. (2020). Cognitive functions of female open skill sport athletes, closed skill sport athletes and nonathletes. Phys Activ Rev, 8(2), 23-29. doi: 10.16926/ par.2020.08.18 [in English]

Predelskaya, R.A.(2015). Gendernye razlichiya cennostnogo motivacionnoj napravlennosti lichnosti bokserov $v$ organizacii processa sportivnoj podgotovki [Gender differences in the value of the mattification orientation of the personality of boxers in the organization of the process of sports training]. (Master's thesis). GCOLIFK, Moscow. [in Russian]

Radionov, A.V.\& Radionov, V.A. (2013). Psihologiya detsko-yunosheskogo sporta [Psychology of youth sports]. Moscow: Fizicheskaya kultura. [in Russian]

Ryasnaya, I., Shevchenko, A. \& Shevchenko, I. (2014). Znachenie morfofunkcionalnyh osobennostej organizma sportsmenok zanimayushihsya boksom [The value of morphological and functional characteristics of the body of athletes involved in boxing]. Sportivnij visnik Pridniprov'ya. Dnipropetrovsk: Innovaciya, 3,103-105. [in Russian]

Saktaganova, T.S. (2018). Specialnaya psihologicheskaya podgotovka vysokokvalificirovannyh zhenshin-bokserov (na primere sbornoj komandy Kazahstana) [Special psychological training 
of highly qualified female boxers (for example, the national team of Kazakhstan)] (Master's thesis). Lesgaft National State University, St. Petersburg. [in Russian]

Shakhlina, L. \& Chistyakova, M. (2020). Psihofiziologicheskie osobennosti sportsmenok, specializiruyushihsya $v$ dzyudo [Psychophysiological features of female athletes who are engaged in judo]. Visnyk Kamianets-Podilskoho natsionalnoho universytetu im. Ivana Ohiienka. Fizychne vykhovannia, sport i zdorovia liudyny,18, 66-69. doi:10.32626/2309-8082.2020-18. 66-69 [in Russian]

Shahlina, L.G. (1999). Problemy polovogo dimorfizma v sporte vysshih dostizhenij [Problems of sexual dimorphism in elite sports]. Teoriya i praktika fizicheskoj kultury, 6. Retrived from: http://sportlib.info/Press/TPFK/1999N6/p51-55.htm [in Russian]

Shakhlina, L.Y.-G. \& Kovalchuk, N.V. (2018). Sovremennoe predstavlenie ob osobennostyah sportivnoj podgotovki zhenshin. [A contemporary view of the peculiarities of female sports preparation]. Sportyvna medytsyna i fizychna reabilitatsiia. 1, 3-14. [in Russian]

Shevchenko,T.A.(2014). Obosnovanie ispolzovaniya genderno differencirovannogo podhoda $v$ sportivnoj deyatelnosti [Rationale for application gender differentiated approach in the sports activities. Uchennyye zapiski. 7 (113), 189-192. DOI: 10.5930/issn.1994-4683.2014.07.113. p189-192 [in Russian]

Volkov, L.V. (1981). Fizicheskie sposobnosti detej i podrostkov [Physical abilities of children and adolescents]. Kiev: Zdorovye [in Russian]

Vorontsov, A.(2020). Zasoby bilateralnoho navchannia $v$ trenuvanni divchat ta yuniorok u boksi [Means of bilateral teaching in the training of girls and juniors in boxing]. Naukovyi chasopys NPU imeni M.P. Drahomanova. Seriia 15: Naukovo - pedahohichni problemy fizychnoi kultury (fizychna kultura i sport). 4(124), 14 -19. DOI :10.31392/NPU-nc.series 15.2020.4(124).02 [in Ukrainian]

Vorontsov,A.I. (2020). Tekhniko - taktychna pidhotovka yuniorok u boksi z urakhuvanniam osoblyvostei psykholohichnoho typu [Technical-tactical preparation of juniors in boxing taking into account peculiarities of psychological type]. Visnyk Zaporizkoho natsionalnoho universytetu. Fizychne vykhovannia ta sport. 1, 95-101. DOI: 10.26661/2663-5925-2020-1-13 [in Ukrainian]

Vorontsov, A.I. (2019). Analiz vozrastnogo cenza devochek v uchebnoj programme po boksu dlya dyussh. [Analysis of the age qualification of girls in the boxing curriculum for youth]. Aktualni problemi fizichnogo vihovannya riznih verstv naselennya 2009 [Current problems of physical education of different segments of the population 2009] Kharkiv: Kharkivska derzhavna akademiia fizychnoi kultury, 35-48. Retrieved from: http://journals.uran.ua/hdafk-tmfv [in Russian]

Vysochina, N., \& Vorobiova, A. (2019). Basic psychological factors affecting athletes' training. Pol. J. Tourism, 26(2), 21-26. [in English]

Zadorozhna, O., Briskin, Yu., Pityn, M., Perederiy A. \& Neroda N. (2020) Tactical training of elite athletes in Olympic combat sports: practice and experience. Trends in sport Sciences. 27(2). P. 71-85. DOI: 10.23829/TSS.2020.27.2-4[in English]

Zadorozhna, O., Briskin, Yu., Sosnovskyy, D., Romanyuk R., Ryhal V. (2019). Stavlennia fakhivtsiv z boksu do realizatsii taktychnoi pidhotovky na riznykh etapakh bahatorichnoho udoskonalennia sportsmeniv [Attitude of experts in boxing to implemenation of tactical training at different statges of athletes long-term development]. Naukovyi chasopys Natsionalnoho pedahohichnoho universytetu imeni M.P. Drahomanova. Seriia No 15. Naukovo-pedahohichni problemy fizychnoi kultury (fizychna kultura i sport). 8(116), 46-51. Retrived from: https:// spppc.com.ua/index.php/journal/issue/view/9/116-pdf [in English] 